\title{
THE ROLE OF CROWDFUNDING IN REDUCING THE EQUITY GAP IN POLAND
}

\section{INTRODUCTION}

Technology changes the way financial intermediaries act. It is noticeable especially in Western European countries, both in the banking sector (for example Revolut or N26) and the capital market sector, where the use of equity crowdfunding platforms (for example Seeders and Crowdcube) by early stage companies for capital raising is becoming increasingly popular. These platforms are connecting entrepreneurs (issuers) and investors, acting as intermediaries in the conclusion of transactions on financial instruments. The importance of equity crowdfunding can be demonstrated by the value of transactions carried out with the use of such platforms, which in 2017 reached GBP333 million in the UK, and EUR211 million in the countries of continental Europe. The growing importance of equity crowdfunding has made it the subject of many studies, such as those carried out by Agrwal, Catalini and Goldfarb, ${ }^{1}$ or Ashlers, Cumming, Guenther and Schweizer. ${ }^{2}$ This technological revolution has also reached the Polish capital market with the recent regulation from 21 April 2018, which allows public offerings up to EUR1 million to be carried out without a prospectus or memorandum. This enables public offerings organized by equity crowdfunding platforms.

Taking the above into consideration, we decided to analyse the development of equity crowdfunding in Poland due to its growing popularity and the changes to Polish law. The main purpose of the article is to characterize equity crowdfunding in Poland and place it among other sources of equity capital. The hypothesis to be tested is that equity crowdfunding influences the reduction of the equity gap among Polish early stage companies.

The paper is organized as follows: the introduction, four sections and conclusions. The introduction presents the aim of the paper and hypothesis. In the first section we define the equity gap and describe the capital sources for SME. In the second, equity crowdfunding is clarified and a literature review is presented. Next, we present research on companies raising capital through equity crowdfunding platforms and the parameters of such offers. In this part

\footnotetext{
1 Agrwal, Catalini, Goldfarb (2014): 63-97; (2015): 253-274.

2 Ashlers, Cumming, Guenther, Schweizer (2015): 955-980.
} 
we also verify the stated hypothesis. In last and final section, we compare the obtained results with those presented in the literature and determine the areas for further research.

The obtained results contribute to the literature on the subject by characterizing equity crowdfunding in Poland, placing it among other sources of equity capital and verifying its impact on reducing the equity gap. In addition, the authors presented their definition of equity crowdfunding.

\section{EQUITY GAP AMONG POLISH COMPANIES}

Micro, small and medium enterprises are a flywheel of the Polish economy. They are the largest non-financial group of companies in Poland that contribute to jobs creation and GDP. These entities develop their economic activity on the basis of their own capital, and they identify the lack of capital sources as one of the main barriers to expansion. At the end of 2016, MSME's accounted for $99,8 \%$ of 2.01 million non-financial entities operating in Poland. ${ }^{3}$ According to the Polish Agency for Enterprise Development (PAED) report, such companies accounted for $48.63 \%$ of GDP in 2008-2015, calculated by Statistics Poland (GUS), thus significantly more than large companies, which generated $23.96 \%$ of GDP.

The evidence for MSME's importance for the Polish economy is revealed through the creation of new jobs. By the end of 2015, 6.2 million people were employed by MSME's, which is $68.7 \%$ of all the employed in Poland. ${ }^{4}$

The Polish Agency for Enterprise Development does not reveal the data on micro enterprises investments, but for those categorized as SME's, the most popular capital source was their own capital $-60 \%$ of investment spending in 2015. Moreover, those companies used loans and credit as $21 \%$ of capital sources and $6 \%$ of foreign capital, with no other relevant sources during the given period.

In the PAED report, R\&D expenditures in 2016 among Polish companies totaled PLN11.7 billion, which was a $40 \%$ growth compared to $2015 .^{5}$ Those spendings were mainly the result of large enterprises that accounted for $60.4 \%$ of R\&D, compared to medium companies $-21.3 \%$, small $9.5 \%$ and micro $8.8 \%$. In the report, entrepreneurs revealed that the main causes of innovation not being implemented were the high costs and the inability to fund them using internal capital sources. One of the key barriers (ranked as fifth) to funding innovation through external financing was lack of either credit or the availability of venture capital (VC) and private equity (PE) funds.

According to the research on entrepreneurship and innovation in Poland, one of the main barriers to growth is lack of capital and the high cost of ob-

\footnotetext{
3 PARP (2018): 12.

4 PARP (2018): 21.

5 PARP (2018): 43.
} 
taining it. Ziemba and Świeszczak summarized the review of Polish literature, in which they pointed out that when asked to identify the most common business difficulties Polish entrepreneurs indicated the limited financial resources (especially at the beginning of their operations), since they are insufficient for financing the investment decisions. In addition, their literature review shows that SMEs are struggling with access to external sources of financing due to the high uncertainty of their business activity, high capital costs and more stringent formal requirements. They also indicated that access to capital was limited by no evidence of good financial standing and lack of plans confirming the high probability of investment implementation. ${ }^{6}$ Those limitations are also confirmed by empirical data. In the World Economic Forum The Global Competitiveness Index 2018 report, ${ }^{7}$ respondents among Polish entrepreneurs pointed out key barriers to growth of their business. The main one is highly complicated tax regulations (18\% of respondents), while $7 \%$ indicated the lack of funding sources. Limited access to capital is related to the equity gap, first defined by Harold Macmillan ${ }^{8}$ in the 1929 Economists and Businessmen Committee report. According to the report, short- and long-term capital was not available to the British small and medium enterprises due to the banks' reluctance to provide it. The factors behind this were identified as cultural and historical conditions, lack of bank employees' competence for effectiveness evaluation, as well as poor organizational conditions. Those factors pushed companies to look for the funding locally or through IPOs. The problem appeared for funding between GBP5,000 and GBP200,000. As the report stated, this amount was not available locally and it was not enough to go public, because of the IPO's costs. That is why the lack of capital between GBP5,000 and GBP200,000 was named the equity gap or Macmillan gap.

In the literature, the mismatch between capital demand from SMEs and supply from financial institutions (banking and market sector) is called the financing gap, equity gap or liquidity gap. ${ }^{9}$ The financing gap means there is a lack of funding sources, whether equity or debt capital. The equity gap is related to the lack of funding for operational or investment activities. The liquidity gap is defined as the situation in which capital supply and demand are mismatched, which leads to no agreement between them. It is significant that those gaps are not the consequence of a lack of capital, but rather of system and institutional restrictions between supply and demand. The general shortage of capital only occurs in extraordinary situations, such as war, political disturbance or financial crisis. ${ }^{10}$ What is more, the definitions of gaps in the literature are inconsistent and ambiguous. All of them are treated equally, because of their relation to limitations of capital supply - the only difference is the type of capital (one's own, outside, general).

\footnotetext{
${ }^{6}$ Ziemba, Świeszczak (2013): 491.

7 World Economic Forum (2018).

8 Thomas (1929).

9 Górka (2012): 210-224; Brzozowska (2009): 66-75; Prędkiewicz (2013): 129-143.

10 Kozłowski (2016): 313-323.
} 
When discussing the equity gap, companies have various ways of obtaining equity, depending on the stage they are currently in. The seed capital, for ideas that are not yet an enterprise or do not sell, produce or provide goods/ services, is $3 \mathrm{~F}$ funding (founders, family and friends), business angels (BA) and venture capital funds. The funding is most often used to build a prototype or create a business model for the idea. In the next stage (start-up), when the prototype of the product or service is ready, the companies lack the capital to enter the market (marketing, distribution network). In this stage there is one more funding source - another form of $\mathrm{VC}$, namely later stage financing. In the expansion stage, companies can reach the stock exchange, especially an alternative stock exchange (for example NewConnect in Poland or AIM in United Kingdom). In the maturity stage, there are more investors on the market interested in financing the companies, like investment funds and PE, as well as individual investors. Because of their size, most of the companies that face the equity gap are those in the first three stages - seed, start-up and expansion.

The technology shift significantly influences the financing sources. Due to common access to computers, which enables digitization of documentation and even more common access to the Internet, which facilitates information exchange and capital flow, new and alternative sources of financing were developed. Most of them are web platforms operating on the P2P model (peer-to-peer), enabling the direct connection between investors and founders (entrepreneurs). Among other financing sources, we can include P2P Consumer Lending, Invoice Trading, P2P Business Lending or crowdfunding. ${ }^{11}$

One of the alternative financing methods concerning equity gap minimization is a certain type of crowdfunding - equity crowdfunding. Equity crowdfunding is presented in the literature as a tool for companies in early stages to collect needed capital. ${ }^{12}$ Other models can have an impact on the financing gap or liquidity gap. In the next section we concentrate on crowdfunding and companies' funding sources.

\section{EQUITY CROWDFUNDING AS A COMPANY'S FUNDING SOURCE}

In this paper we concentrate on equity-based crowdfunding, which can be defined as a type of investment. Szopa points out that in the investment model, the investor can acquire equity or a share of company's profits as well as additional discounts on products or other financial rewards. ${ }^{13}$ The authors of this paper suggest defining equity crowdfunding as a 'model in which investors receive an equity-based instrument (that incorporates corporate and property

\footnotetext{
11 University of Cambridge (2019a).

12 Wilson, Testoni (2014): 1-14.

13 Szopa (2018): 33-46.
} 
rights) with additional bonuses in exchange for their money transfers, which are acquired through the crowdfunding platform.'

The given definition is rather process-orientated. From the equity crowdfunding initiators' perspective, they can achieve many other non-financial benefits besides raised capital. For example, they can: attract brand ambassadors (investors that after acquiring shares identify themselves as a part of the company and promote it), create a network (which may help in building up a distribution network), or get feedback on the product's service market potential (as a sign from investors they send buying shares).

There are three groups of participants that are essential for crowdfunding efficiency: the initiators, capital owners and the operators of crowdfunding platforms. The initiator, just like the capital owner, can be any individual or institution. The operator of the platform provides the infrastructure to start cooperation between the initiators and investors. This infrastructure is basically a web platform, which enables the information on the funding and the benefits to be presented in an in organized manner, and facilitates the realization of payments and communication between parties. Crowdfunding platforms can operate in one of the five models: ${ }^{14}$ donation-based, reward-based, pre-sale, equity-based or lending-based.

The importance of equity crowdfunding, as a source of capital, is underlined by the data presented in University of Cambridge report. ${ }^{15}$ The total value of transactions in the European equity crowdfunding platforms (excluding the United Kingdom) was EUR211 million in 2017, of which Polish transactions were EUR0.76 million (2017 was a period before the major changes in Polish law on public offerings, which are specified in the next section, and which had a huge impact on the shift in transactions in 2018). Both values remained steady compared to 2016, when the European equity crowdfunding market reached EUR219 million and Polish EUR0.9 million. The European equity crowdfunding market has grown immensely when we consider British market, which in 2017 was GBP333 million (up by $22 \%$ year-over-year). ${ }^{16}$

Research on equity crowdfunding in the literature refers to many commonly found theories, like the signaling theory or pecking order theory. In the Polish and international literature there is a lack of quantitative research on how equity crowdfunding influences equity gap minimization among early stage companies.

The evolution of equity crowdfunding has been the subject of many studies. From 2012 on, there has been a dispute over the factors facilitating equity crowdfunding campaigns. One of the most important was conducted by Mollick, who analysed 48,500 projects of the total value over USD237 million ${ }^{17}$ and pointed out that the success of the campaign relies on personal connections (social network around the project) and the quality of the project. What

\footnotetext{
$14 \mathrm{KNF}$ (2017).

15 University of Cambridge (2019a).

16 University of Cambridge (2019b).

17 Mollick (2014): 1-16.
} 
is more, Mollick suggested that the type of the project and its success in terms of raised capital depends on the geographical localization (distance between the initiator and the network that is its first supporter). The adaptation of signalling theory to equity crowdfunding was done by Ashlers, Cumming, Guenther and Schweizer, who conducted empirical research to verify the efficiency of the signals' impact on the investors' willingness to invest money. ${ }^{18}$ According to their findings, limiting the information asymmetry (for example presentation of the risk factors) may substantially influence the campaign. In terms of behavioural finance, Gordon, Anindya and Sunil suggest that introduction of the funding threshold (setting the minimum value of the funding that has to be reached in order to close the campaign) helps to prevent the herding effect among investors (postponing the decision about investment) or limit the information cascades that affect the market. ${ }^{19}$ Research of this kind is most often empirical, with not many theory-based studies available. One of them though is Bellerflamme, Lambert and Schwienbacher, which concentrates on the theoretical principles behind entrepreneur's choice between two forms of equity crowdfunding - pre-ordering and equity crowdfunding based on sharing the profits. ${ }^{20}$

Theoretical considerations on the impact of equity crowdfunding on equity gap minimization were conducted by Deffains-Crapsky and Sudolska. ${ }^{21}$ These authors pointed out that equity crowdfunding is a competitor for $\mathrm{BA}$ and $\mathrm{VC}$ when considering the funding for innovative projects. They identified substantial differences between capital allocation among the mentioned sources, emphasizing that capital obtained through crowdfunding was dispersed while BA and VC funding was highly concentrated. They indicated three areas of necessary research: ${ }^{22}$ (1) capital allocation through equity crowdfunding platforms, (2) an analysis of the cognitive selection process employed by investors active on crowdfunding platforms and BA while making investment decisions, and (3) analysis of the consumer-investor role before and after the decision to invest in the project, in order to understand the impact of uncertainty of the projects (considering that investors evaluate the project as a consumer, limiting the investment risk based on its market opportunities).

Empirical studies of the impact of equity crowdfunding on equity gap minimization in Norway was conducted by Lund. ${ }^{23}$ His results are ambiguous and depend on the reader's perception. He indicates that $75 \%$ of the analysed companies that used crowdfunding platforms qualified as an early stage, including the idea and pre-seed stage. Simultaneously, Lund pointed out there was no consensus on the identification of an equity gap among the investors

\footnotetext{
18 Ashlers et al. (2015): 955-980.

19 Gordon, Anindya, Sunil (2016): 478-496.

20 Bellerflamme, Lambert, Schwienbacher (2014): 585-609.

21 Deffains-Crapsky, Sudolska (2014): 3-19.

22 Deffains-Crapsky, Sudolska (2014): 3-19.

${ }^{23}$ Lund (2017).
} 
taking part in the research - in their opinion it occurs in later stages than those of idea and pre-seed. Lund's conclusion was that equity crowdfunding was not the right tool to minimize or close the equity gap in the Norwegian risk market.

Walthoff-Borm, Schwienbacher and Vanacker presented an interesting study on using equity crowdfunding as a source of capital, ${ }^{24}$ as their analysis on capital sources hierarchy (pecking order theory) compared companies using crowdfunding platforms with those that did not. The results revealed that companies choose crowdfunding when there are no other options left to raise capital.

Among Polish studies, there is an analysis from Koziol-Nadolna concerning the use of crowdfunding by Polish companies. ${ }^{25}$ The results proved that Polish companies rarely use that alternative source of funding, and the reasons for this are a lack of knowledge of equity crowdfunding by entrepreneurs, reluctance to prepare a professional business offer and unfavourable legal conditions. Waszkiewicz suggested that crowdfunding meets the expectations of micro-, small- and medium-sized enterprises in Poland, ${ }^{26}$ but it should be used mainly by start-ups (in a pre-sale model) and medium-sized enterprises (in an investment model), referring to the possibility of business model verification in the early stages (start-up) and the benefits of the campaign leading not only to attracting investors but also to creating business networks (medium-sized enterprises). Waszkiewicz stated that equity crowdfunding can effectively close the equity gap, influencing the rapid growth of innovation and socially important business projects. A survey on Polish companies using crowdfunding was conducted by Kordela ${ }^{27}$ and showed that even if the crowdfunding was available as a source of capital, companies rarely used it. Her conclusion was that equity crowdfunding in Poland developed slowly and did not play an important role as a source of funding in the early stages.

\section{ANALYSIS OF EQUITY CROWDFUNDING DEVELOPMENT IN POLAND DURING 2015-2019}

In this section of the article we attempt to characterize equity crowdfunding as a source of capital for enterprises in Poland and place it among other equity capital sources. In addition, an attempt is made to verify the main hypothesis of this study, which states that equity crowdfunding influences the minimization of the equity gap among Polish early stage companies.

\footnotetext{
${ }^{24}$ Walthoff-Borm, Schwienbacher, Vanacker (2018): 513-533.

25 Kozioł-Nadolna (2018): 71-90.

${ }_{26}$ Waszkiewicz (2018): 159-169.

27 Kordela (2018): 179-196.
} 


\section{The issuers using equity crowdfunding}

The research is based on 37 equity crowdfunding campaigns that were available up to 28 February 2019, of which 25 were from Beesfund, 7 from Crowdway and 5 from FindFunds. The scope of information differed for each offer, which was highlighted the research.

Among equity crowdfunding campaigns from 2015-2019, most were run by tech sector companies (Table 1), including Disco VR (electronic entertainment parks) or Bivrost (augmented reality products). Even though most of the campaigns were organized for tech sector companies, the structure of the campaigns was relatively diversified as sectors like alcohol production (Jastrzębie brewery, Doctor Brew), services (MC2 Innovations, City Inspire) and production (Kunagone, Stara Mleczarnia) account for more than a 10\% share. Given the results shown in Table 1, we can state that there are no limitations concerning the sectors for potential issuers.

Table 1

Campaigns by industry 2015-2019

\begin{tabular}{|l|c|c|}
\hline \multicolumn{1}{|c|}{ Industry } & Number & Share \\
\hline Computer games & 3 & $8.11 \%$ \\
\hline Alcohol production & 5 & $13.51 \%$ \\
\hline Production & 4 & $10.81 \%$ \\
\hline Technology & 12 & $32.43 \%$ \\
\hline Finance & 3 & $8.11 \%$ \\
\hline Services & 5 & $13.51 \%$ \\
\hline Sport & 1 & $2.70 \%$ \\
\hline Fashion & 1 & $2.70 \%$ \\
\hline Gastronomy & 3 & $8.11 \%$ \\
\hline
\end{tabular}

Source: authors' own study based on Beesfund, Crowdway, and FindFunds.

Most of the companies running equity crowdfunding campaigns decided to raise funds during their first or second year of existence (Table 3). The information on when the company was established and when it ran the campaign was obtained for 32 companies. Most of them decided to go public just after the registration in KRS $-47 \%$ of issuers. Considering the campaigns organized in the second year of the company's existence, it increased up to $69 \%$. We assume that equity crowdfunding can be used by the companies regardless of how long they have been in operation and the success of the campaign depends on its investment attractiveness, regardless the branch it operates in. 
Table 2

Conducting the campaign in relation to the establishment of the company in 2015-2019

\begin{tabular}{|l|c|c|}
\hline Years from company establishment & Number of companies & Share \\
\hline First & 15 & $46.88 \%$ \\
\hline Second & 7 & $21.88 \%$ \\
\hline Third & 5 & $15.63 \%$ \\
\hline Fourth & 2 & $6.25 \%$ \\
\hline Fifth & 1 & $3.13 \%$ \\
\hline More than five & 2 & $6.25 \%$ \\
\hline
\end{tabular}

Source: authors'own study based on Beesfund, Crowdway, and FindFunds.

Most of the companies that ran campaigns employed a few people. The information on employment was obtained for 32 companies, of which for 17 it was not more than 5. According to the definition given by the European Commission, all of the companies were micro- (less than 10 employees) or small-sized enterprises (between 11 and 50 employees).

Table 3

Employment among companies

\begin{tabular}{|l|c|c|}
\hline \multicolumn{1}{|c|}{ Employees } & Number of companies & Share \\
\hline $1-5$ & 17 & $53.12 \%$ \\
\hline $6-10$ & 7 & $21.88 \%$ \\
\hline $11-50$ & 8 & $25.00 \%$ \\
\hline
\end{tabular}

Source: authors' own study based on Beesfund, Crowdway, and FindFunds.

For only 20 out of 37 projects (55\%) were data available on the revenue generated by the company, of which 19 presented the net income (Table 4). A full financial statement was available for only two projects and financial liabilities were given by one project. The companies that were raising the capital were relatively small, with revenues below PLN1 million in the year before the campaign, and they were generating losses.

Table 4

Companies sharing financial statements as a part of a crowdfunding campaign

\begin{tabular}{|c|c|c|c|}
\hline Value & Revenue & Net profit & Net loss \\
\hline Below PLN1 million & 11 & 4 & 11 \\
\hline Above PLN1 million & 9 & 0 & 1 \\
\hline
\end{tabular}

Source: authors' own study based on Beesfund, Crowdway, and FindFunds. 
The data presented in this section proves that equity crowdfunding campaigns were run for relatively small companies (in terms of employment and financial data) in the early stages (which were established not long ago) operating in high tech industries (tech, computer games) or more traditional ones (services, alcohol production). The obtained results allowed the main goal of the paper to be accomplished, namely to characterize equity crowdfunding in Poland. In the Chart 1 we present the place of equity crowdfunding among other sources of equity capital for enterprises.

\section{Chart 1}

Crowdfunding among other equity capital sources, depending on the phase of company development
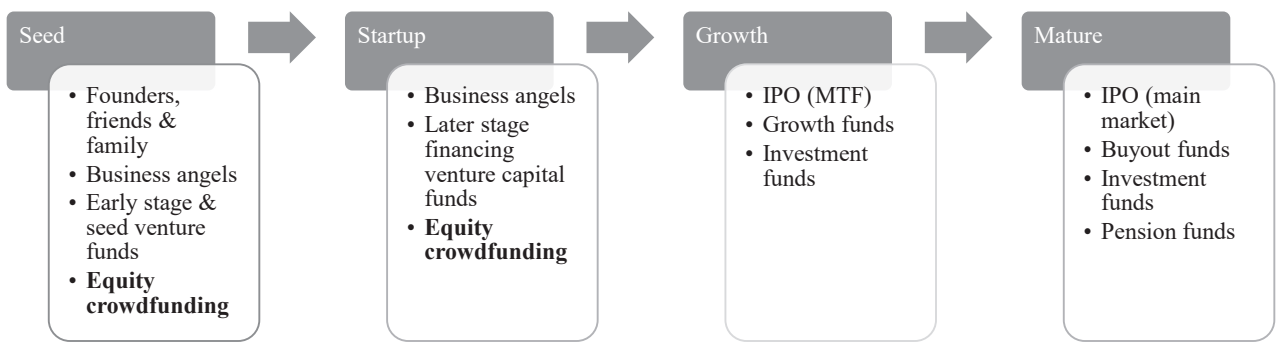

Source: authors' own work.

\section{Public offerings parameters in equity crowdfunding}

We obtained data regarding the offering parameters for 35 equity crowdfunding campaigns run on the analysed platforms (Table 5). The total value of raised capital was over PLN25 million, which amounts to $66.4 \%$ of the capital expected by the issuers. Among the analysed group, the biggest raise was run by Wisła Kraków (PLN4 million), ahead of two brewery companies Doctor Brew (PLN3.2 million) or Jastrzębie Brewery (PLN2.4 million).

Table 5

Equity crowdfunding public offerings statistics for 2015-2019

\begin{tabular}{|l|c|}
\hline \multicolumn{1}{|c|}{ Parameter } & Value \\
\hline Expected offer value [PLN] & $38,707,299$ \\
\hline Raised capital [PLN] & $25,693,983$ \\
\hline Average value of the offers [PLN] & 694,432 \\
\hline Median [PLN] & 400,000 \\
\hline
\end{tabular}




\begin{tabular}{|l|r|}
\hline Max value of the raised capital [PLN] & $4,000,000$ \\
\hline Min value of the raised capital [PLN] & 18,900 \\
\hline$\%$ average funding rate & $68.98 \%$ \\
\hline Average number of investors [units] & 544 \\
\hline Median number of investors [units] & 150 \\
\hline
\end{tabular}

Source: authors' own study based on Beesfund, Crowdway, and FindFunds.

The value of capital raised during equity crowdfunding campaigns ranged from PLN19,000 to PLN4 million, with a median equal to PLN400,000. The median is a result of legal regulations (Act on Public Offering), which up to 21 April 2018 allowed offers without a prospectus, for which expected gross inflow do not exceeded EUR100,000 (as a consequence, most companies set the inflow at PLN400,000). The change in legal regulations is explained later in the paper. The raising of the capital at the expected level was achieved in 15 cases ( $42 \%$ of the analysed campaigns) while the average funding rate was $69 \%$ for the whole data set, which was below the European average presented in the Cambridge report $-81 \% .^{28}$

Dispersion among investors measured by the average (distorted by the Wisła Kraków offering with 9,000 investors, and Jastrzębie brewery with 3,000 investors) as well as the median proved that for crowdfunding offers it was much higher than for private placement on the alternative stock exchange run by WSE - NewConnect (on average not more than 50 investors). It is a positive sign, not only because of the risk diversification among investors, but, more importantly, also because of the market opening for a broader group of potential investors. The fragmentation of shareholders also proved that in terms of the analysed offers, the crowdfunding acted as expected - it enabled the crowd to fund the project.

We found the information about the date of offering for only 30 campaigns. In case of the number of projects carried out and the value of capital obtained, a clear upward trend is visible (Graph 1). This proves the popularity increase of crowdfunding equity in Poland as a source of raising capital.

Among the analysed campaigns (Table 6), most of them were carried out by tech industry companies (32\%), while alcohol producers raised the most capital (72\%). If we add computer game companies to the tech industry, they accounted for $40 \%$ of all offers and $33 \%$ in terms of raised capital for the intangible assets sector. Financial and services were also popular sectors among investors, with the highest success rate (excluding sports, for which there was only one offering).

${ }^{28}$ University of Cambridge (2019a). 


\section{Graph 1}

Offerings by year of conduction

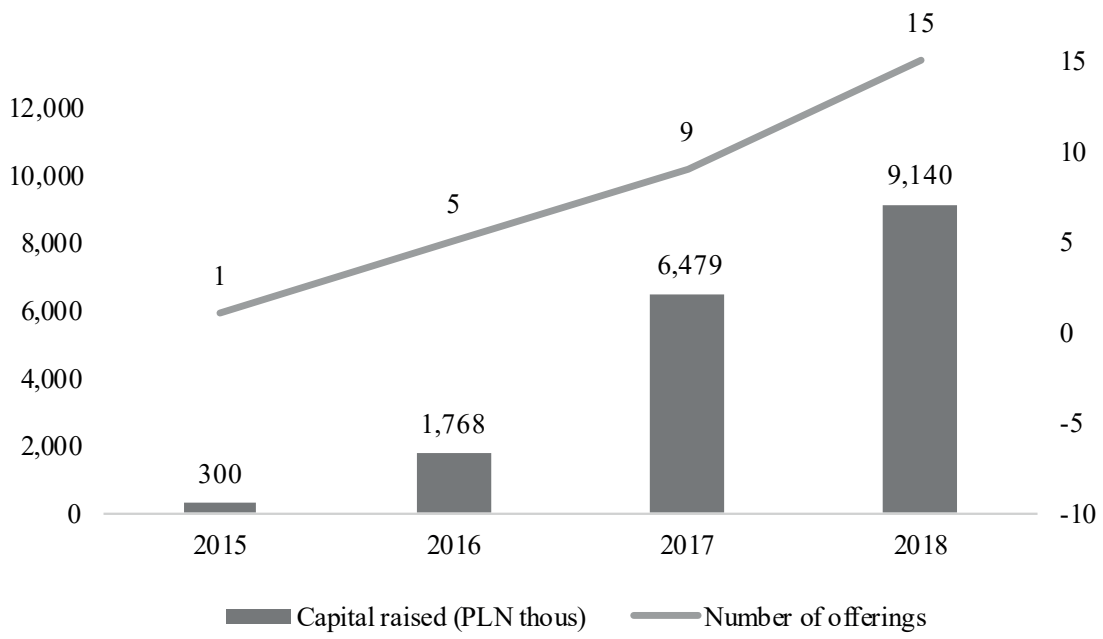

Source: authors' own study based on Beesfund, Crowdway, and FindFunds.

Table 6

Public offerings by sectors

\begin{tabular}{|l|c|c|c|c|}
\hline \multicolumn{1}{|c|}{ Sector } & $\begin{array}{c}\text { Offer value } \\
\text { [PLN] }\end{array}$ & $\begin{array}{c}\text { Capital raised } \\
\text { [PLN] }\end{array}$ & $\begin{array}{c}\text { \% Average } \\
\text { Funding rate }\end{array}$ & $\begin{array}{c}\text { Number of } \\
\text { campaigns }\end{array}$ \\
\hline Computer games & $3,442,000$ & $2,677,658$ & $78 \%$ & 3 \\
\hline Alcohol production & $10,804,020$ & $6,990,612$ & $65 \%$ & 5 \\
\hline Production & $1,599,968$ & $1,042,465$ & $65 \%$ & 4 \\
\hline Tech & $8,240,028$ & $5,871,667$ & $71 \%$ & 12 \\
\hline Finanse & $1,001,500$ & $1,001,500$ & $100 \%$ & 3 \\
\hline Services & $2,819,979$ & $2,287,926$ & $81 \%$ & 5 \\
\hline Sport & $4,000,000$ & $4,000,000$ & $100 \%$ & 1 \\
\hline Fashion & 400,000 & 65,520 & $16 \%$ & 1 \\
\hline Gastronomy & $6,399,805$ & $1,756,635$ & $27 \%$ & 3 \\
\hline
\end{tabular}

Source: authors' own study based on Beesfund, Crowdway, and FindFunds.

In order to verify the hypothesis, the capital raised through equity crowdfunding platforms was arranged by values (Table 7) and which of them qualify as a Macmillan equity gap was verified. In the literature, the Macmillan gap is within the range from GBP5,000 up to GBP200,000, which for this particular study was assumed to be between PLN25,000 and PLN1 million. 
Table 7

Deals minimizing the Macmillan gap

\begin{tabular}{|l|c|}
\hline \multicolumn{1}{|c|}{ Range } & Value \\
\hline From PLN25,000 up to PLN1 million [units] & 29 \\
\hline Value of raised capital & $9,267,651$ \\
\hline
\end{tabular}

Source: authors' own work.

According to the data presented in Table 7, 29 out of 35 public offerings (74\%) qualified as falling within the range defined as the Macmillan gap. Those companies raised PLN9.3 million in total (36\% of the total value of analysed deals). The result of the analysis in terms of companies raising capital as well as offers themselves allows acceptance of the hypothesis that equity crowdfunding influences the reduction of the equity gap among Polish early stage companies.

\section{DISCUSSION AND FURTHER RESEARCH}

The conducted research fits the postulates of Deffains-Crapsky and Sudolska, ${ }^{29}$ who pointed out the necessity of capital allocation mechanism verification within equity crowdfunding platforms. The research is based on the analysis of companies raising capital as well as the process of raising capital itself.

The obtained results, despite the difference in methods being used (comparative and descriptive analysis vs questionnaire survey), allow the impact of equity crowdfunding on equity gap minimization in Poland to be compared with the results presented by Lund for the Norwegian market. ${ }^{30}$ Our conclusion is that Polish platforms do minimize the equity gap, which stands in contrast to Lund's conclusion for Norway.

The analysis also established that equity crowdfunding deals in Poland can be characterized by a high level of information asymmetry between the investors and company. This is the result of not sharing detailed financial data within the analysed campaigns, which is necessary for most investors to make investment decisions. That mirrors Agrawal, Catalini and Goldfarb's results for equity crowdfunding deals in the USA. ${ }^{31}$

Our research is also consistent with the discussion on equity crowdfunding in the Polish literature. Although Kozioł-Nadolna's research ${ }^{32}$ showed that innovative companies rarely used this source of capital, our research

\footnotetext{
29 Deffains-Crapsky, Sudolska (2014).

${ }^{30}$ Lund (2017).

31 Agrwal, Catalini, Goldfarb (2014): 63-97.

32 Kozioł-Nadolna (2018).
} 
proved that interest in equity crowdfunding is growing systematically (Graph 1), analogously to the research conducted by Kordela. ${ }^{33}$ What is more, our results suggest that equity crowdfunding is suitable for all companies, regardless their size (especially in terms of employment) - we do not share Waszkiewicz's opinion that equity crowdfunding was only used by startups and medium-sized enterprises. ${ }^{34}$ Considering the changes to legal regulations (a higher public offerings limit, without the need of a prospectus up to EUR1 million from April 2018, and the simplification of promotional campaigns) micro and small enterprises can also take part in equity crowdfunding, profiting from the promotion of the business and network creation around the company.

Although our research allows the impact of equity crowdfunding on equity gap minimization to be verified, there are still many factors that can shape the future of the platforms in Poland. One of the key elements is the regulations on the operators of such platforms. According to the statement of the UKNF (Polish Financial Supervision Authority) on the definition of financial instrument offerings in Article 72 of the Act of 29 July 2005 on Trading in Financial Instruments ${ }^{35}$ even the presentation of the price of a financial instrument can be considered as a brokerage activity, and this requires UKNF permission, which limits the legal risk for platform operators, but on the other hand significantly influences operating platforms. That is because the platforms that did not get a UKNF licence before 21 April 2019, or did not submit an application for UKNF licence to conduct brokerage activities, had to limit their activities with regard to the presentation of financial instrument offerings. It is worth mentioning that, according to Cai's conclusion, ${ }^{36}$ equity crowdfunding cannot eliminate traditional financial intermediaries (brokerage houses) in the current legal environment as they are necessary for this kind of service. Currently there is only one crowdfunding platform operating on the Polish market which is consistent with the legal regulations, and this was not analysed in this paper, due to the fact it was launched in February 2019 and its first campaign was introduced in March 2019 (CrowdConnect.pl). According to the press release, the application to the UKNF was submitted by the biggest platform in Poland - Beesfund. It is expected that before the implementation of the EU regulation on crowdfunding platform providers for business (Regulation of the European Parliament and the Council on European Crowdfunding Providers for Business) the number of active crowdfunding platforms in Poland may be limited. This will not necessarily affect crowdfunding activity, but it may lead to the concentration of activities around fewer platforms.

\footnotetext{
${ }^{33}$ Kordela (2018).

34 Waszkiewicz (2018).

35 KNF (2019).

36 Cai (2018): 965-992.
} 
The important factors in the legal regulations are the changes to the Act on Public Offering. Starting from 21 April 2018, Polish companies raising capital through public offerings of up to EUR1 million do not have to prepare an offering memorandum or prospectus, but only an information document, which is short and simple, including only basic information (for example risk factors and the purpose the funding should be used for). This change was the catalytic event for equity crowdfunding platforms in Poland, as we observed huge growth in new campaigns being announced from the second half of 2018 .

The changes to legal regulations concerning equity crowdfunding should indicate how legal risk is perceived by issuing companies and platform providers. This kind of risk was one of the key factors shaping the overall risk for crowdfunding ${ }^{37}$ and attempts to minimize it will involve more active exploration of equity crowdfunding.

The observed legal changes and the expected implementation of the EU regulation should lead to further growth in the popularity of crowdfunding among companies raising capital (facilitation of the process) as well as investors (limitation of the risk). Equity crowdfunding should be further analysed, especially in terms of equity gap minimization, particularly after the implementation of legal changes.

\section{CONCLUSIONS}

The presented research on equity crowdfunding allowed the main goal of the paper to be accomplished, namely to characterize equity crowdfunding in Poland. The obtained result enabled equity crowdfunding to be placed among other capital sources and confirmed the hypothesis that equity crowdfunding influences the reduction of the equity gap among Polish early stage companies. Among other findings, it is shown that equity crowdfunding in Poland is used by small-sized companies (in terms of employment and financial data) in early stages (which were established not long ago), operating in various sectors. What is more, most of the companies raised the capital that qualifies as the Macmillan gap, that is between PLN25,000 and PLN1 million (74\% of analysed campaigns). Another finding is the high level of information asymmetry between investors taking part in the campaign and the company (mainly because of the lack of available financial data). We also provided our own definition of equity crowdfunding.

The results presented in the paper refer to the period of 2015-2019. Considering the dynamic growth of crowdfunding in Poland and worldwide, it seems necessary to conduct further research on the subject, especially in terms of equity gap minimization. The popularity of this capital source depends on the changes to legal regulation, which were observed in 2018-2019 in Poland, especially considering the change of Act on Public Offerings that

\footnotetext{
${ }^{37}$ University of Cambridge (2019a).
} 
came into force on 21 April 2018, shifting the limit of public offerings without a prospectus up to EUR1 million and facilitating promotional campaigns, as well as the UKNF statement from 29 March 2019 on platform providers and the requirement of a UKNF licence for brokerage activities.

\author{
Michat Łukowski \\ Poznań University of Economics and Business \\ michal.lukowski@ue.poznan.pl \\ https://orcid.org/0000-0002-5626-6508 \\ Piotr Zygmanowski \\ Poznań University of Economics and Business \\ piotr.zygmanowski@ue.poznan.pl \\ https://orcid.org/0000-0002-1601-5544
}

Agrwal, A., Catalini, C., Goldfarb, A. (2014). Some simple economics of crowdfunding, innovation. Policy and the Economy 14(1): 63-97.

Agrwal, A., Catalini, C., Goldfarb, A. (2015). Crowdfunding: geography, social networks and the timing investment decisions. Journal of Economics and Management Strategy 24(2): 253274.

Ashlers, G., Cumming, K., Guenther, C., Schweizer, D. (2015). Signalling in equity crowdfunding. Enterpreneurship Theory and Practice 39(4): 955-980.

Bellerflamme, P., Lambert, T., Schwienbacher, A. (2014). Crowdfunding: tapping the right crowd. Journal of Business Venturing 29(5): 585-609.

Brzozowska, K. (2009). Kapitał wysokiego ryzyka w niwelowaniu luk kapitałowych przedsięwzięć innowacyjnych. Prace Naukowe Uniwersytetu Ekonomicznego we Wrocławiu 48: 66-75.

Cai, W.C. (2018). Disruption of financial intermediation by FinTech: a review on crowdfunding and blockchain. Accouting and Finance 58: 965-992.

Deffains-Crapsky, C., Sudolska, A. (2014). Radical innovation and early stage financing gaps: equity-based crowdfunding challenges. Journal of Positive Management 5(2): 3-19.

Gordon, B., Anindya, G., Sunil, W. (2016). An empirical examination of information hiding and contribution dynamics in online crowdfunding. Information Systems Research 27(3): 478-496.

Górka, K. (2012). Zjawisko luki kapitałowej w finansowaniu mikro-, małych i średnich przedsiębiorstw w Polsce w latach 2007-2011. Ekonomia 4(21): 210-224.

KNF (2017). Raport z prac Zespołu roboczego ds. rozwoju innowacji finansowych (FinTech). $<$ https://www.knf.gov.pl/knf/pl/komponenty/img/Raport_KNF_11_2017_60290.pdf> [accessed 20 March 2019].

KNF (2019). Stanowisko UKNF dotyczące definicji usługi oferowania instrumentów finansowych zawartej w art. 72 ustawy z dnia 29 lipca 2005 r. o obrocie instrumentami finansowymi. $<$ https://www.knf.gov.pl/knf/pl/komponenty/img/Oferowanie_Instrumentow_65197.pdf $>$ [accessed 29 March 2019].

Kordela, D. (2018). Wykorzystanie crowdfundingu w finansowaniu wczesnych faz rozwoju przedsiębiorstwa, [in:] A. Pluszyńska, A. Szopa (eds.), Crowdfunding w Polsce. Cracow: Wydawnictwo Uniwersytetu Jagiellońskiego: 179-196.

Kozioł-Nadolna, K. (2018). Crowdfunding a model otwartej innowacji. Charakterystyka modeli i platform crowdfundingowych w Polsce, [in:] A. Pluszyńska, A. Szopa (eds.), Crowdfunding w Polsce. Cracow: Wydawnictwo Uniwersytetu Jagiellońskiego: 71-90.

Kozłowski, W. (2016). Systemowe wspieranie sektora mikro, małych i średnich przedsiębiorstw w ograniczaniu luki finansowej. Marketing i Zarządzanie 2(43): 313-323.

Lund, H. (2017). Mind the GAp. Is There an Equity Gap in Norway, and Can Equity Crowdfunding Close It? Bergen: Norwegian School of Economics.

Mollick, E. (2014). The dynamics of crowdfunding: an exploratory study. Journal of Business Venturing 29(1): 1-16. 
PARP (2018). Raport o stanie sektora małych i średnich przedsiębiorstw w Polsce. Warsaw.

Pluszyńska, A. (2018). Crowdfunding - historia i definiowanie, [in:] A. Pluszyńska, A. Szopa (eds.), Crowdfunding w Polsce. Cracow: Wydawnictwo Uniwersytetu Jagiellońskiego: 13-32.

Prędkiewicz, K. (2013). Granice luki kapitałowej w Polsce. Zeszyty Naukowe Finanse 901: 129-143.

Szopa, A. (2018). Charakterystyka modeli i platform crowdfundingowych w Polsce, [in:] A. Pluszyńska, A. Szopa (eds.), Crowdfunding w Polsce. Cracow: Wydawnictwo Uniwersytetu Jagiellońskiego: 33-46.

Thomas, S.E. (1929). The Macmillan Report. A short summary of its main points prepared for the guidance of students. College, St. Albans, University of Toronto Libraries. <https://ia801405. us.archive.org/9/items/macmillanreports00thomuoft/macmillanreports00thomuoft.pdf $>$ [accesseed 20 March 2019].

University of Cambridge (2019a). Shifting Paradigms. The 4th European Alternative Finance Benchmarking Report. Cambridge.

University of Cambridge (2019b). The 5th UK Alternative Finance Industry Report. Cambridge.

Walthoff-Borm, X., Schwienbacher, A., Vanacker, T. (2018). Equity crowdfunding: first or last resort? Journal of Business Venturing 33: 513-533.

Waszkiewicz, E. (2018). Crowdfunding jako odpowiedź na potrzeby sektora MŚP w Polsce, [in:] A. Pluszyńska, A. Szopa (eds.), Crowdfunding w Polsce. Cracow: Wydawnictwo Uniwersytetu Jagiellońskiego: 159-169.

Wilson., K., Testoni, M. (2014). Improving the role of equity crowdfunding in Europe's Capital Markets. Bruegel Policy Contribution 9: 1-14.

World Economic Forum (2018). The Global Competitiveness Report 2018. <http://www3.weforum.org/docs/GCR2018/05FullReport/TheGlobalCompetitivenessReport2018.pdf $>$ [accessed 20 April 2019].

Ziemba, M., Świeszczak, K. (2013). Bariery rozwoju podmiotów z sektora MSP - ze szczególnym uwzględnieniem możliwości pozyskania kapitału. Finanse, Rynki Finansowe, Ubezpieczenia 64(1): 491-499.

\section{THE ROLE OF CROWDFUNDING IN REDUCING THE EQUITY GAP IN POLAND}

\section{Summary}

The aim of the paper is to verify if equity crowdfunding has an impact on equity gap reduction among early stage companies in Poland. The analysis is based on crowdfunding campaigns organized on the three most popular platforms in Poland during the 2015-2019 period. The presented research on equity crowdfunding allowed the main goal of the paper to be accomplished, namely to characterize equity crowdfunding in Poland. The results obtained also enabled equity crowdfunding to be placed among other equity capital sources for companies in the early stages of development. The results of the study verify the hypothesis that equity crowdfunding has an impact on equity gap reduction among Polish early stage companies. Our key findings prove that equity crowdfunding in Poland is mainly used by relatively small, early stage companies that operate in various sectors. Another finding is that most of the companies raised capital that qualifies as the Macmillan gap. We also proved that there is a relatively high level of information asymmetry among equity crowdfunding campaigns and provided our own definition of equity crowdfunding.

Keywords: equity crowdfunding; equity gap; public offerings; offering company 
